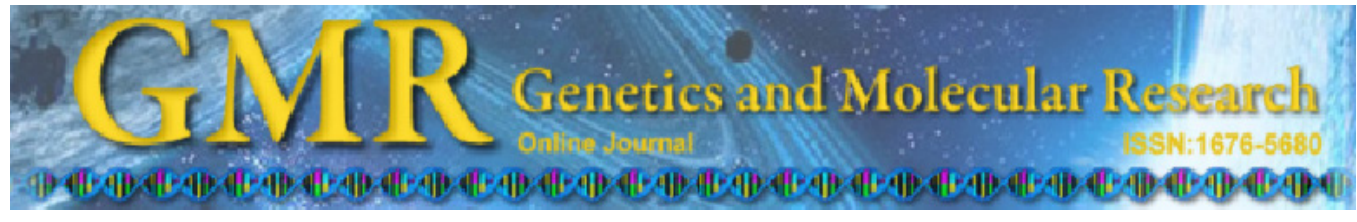

\title{
Genetic diversity of root anatomy in wild and cultivated Manihot species
}

\author{
N.N. Bomfim, D. Graciano-Ribeiro and N.M.A. Nassar \\ Departamento de Botânica, Universidade de Brasília, Brasília, DF, Brasil \\ Corresponding author: N.M.A. Nassar \\ E-mail: nagnassa@rudah.com.br
}

Genet. Mol. Res. 10 (2): 544-551 (2011)

Received October 5, 2010

Accepted October 15, 2010

Published April 5, 2011

DOI 10.4238/vol10-2gmr1093

\begin{abstract}
An anatomical study of roots was conducted on two wild Manihot species, namely M. glaziovii and M. fortalezensis, and two cassava varieties, $M$. esculenta Crantz variety UnB 201 and $M$. esculenta variety $\mathrm{UnB} 122$, to identify taxonomic differences in primary growth. Anatomical characters of cassava roots have been rarely investigated. Their study may help cassava breeders to identify varieties with economically important characters, such as tolerance to drought. We investigated tap and lateral adventitious roots of two specimens of each clone or species. Free-hand cross-sections of roots were drawn; these had been clarified with $20 \%$ sodium hypochlorite solution, stained with $1 \%$ safranin-alcian blue ethanolic solution, dehydrated in ethanol series and butyl acetate and mounted in synthetic resin. Anatomical differences among Manihot species and varieties were found in the epidermal and exodermal cell shape and wall thickness, content of cortical parenchyma, and number of xylem poles. Wall thickness of the epidermis and exodermis of tap root were similar in all species, while in the lateral root there were differences in cell shape and wall thickness. Epidermal cells with thick walls were found in the tap root of all species and in lateral
\end{abstract}


roots of cassava varieties. This character is apparently associated with tolerance to drought and disease. The variation in the number of xylem poles of cassava varieties was larger (4-8) than in wild species (4-6), and appears to support the hybrid origin of cassava.

Key word: Primary growth; Manihot glaziovii; Manihot esculenta; Manihot fortalezensis; Xylem poles

\section{INTRODUCTION}

Wild Manihot species are important for improving cassava, Manihot esculenta Crantz. The root is of interest to research on this biological group, because it is a consumed part of the cultivated plant. Acquiring information on this part may help improve the crop for different affinities. There are scarce reports in the literature on the subject. Our study is probably the first one on the subject.

Economic characters such as tolerance to drought and insects are found in wild Manihot species (Nichols, 1947; Nassar, 1986). Knowing more about root anatomy would help in understanding the mechanism and nature of these characters.

Hybridization between Manihot species occurs naturally (Nassar, 2001; Chacón et al., 2008) and could lead to variation and diversity in different characters, either of the stem, flower or fruit. This presumed diversity may have resulted as a result of domestication action on all material. Also, knowledge of the anatomy of the cultivated plant compared to the wild species may contribute to information on the domestication.

In this article, we present the findings on the anatomy of 2 wild Manihot species and 2 varieties of cassava and their economic significance.

\section{MATERIAL AND METHODS}

Two wild Manihot species, namely Manihot glaziovii Muller and M. fortalezensis Nassar et al., and two varieties, M. esculenta Crantz variety UnB 201 and M. esculenta variety UnB 122, were our study material.

M. glaziovii and M. fortalezensis were collected from Ceará State, northeast region of Brazil, and grown at the experimental station of Universidade de Brasília. $M$. esculenta variety UnB 201 was collected from Amapá State, northern region of Brazil, while the variety UnB 122 was selected from the progeny of the M. esculenta and M. anomala Pohl hybrid. All specimens were kept with the live collection at the Universidade de Brasília, Brasília, Brazil.

Adventitious roots in primary growth were collected at 1-3 months after planting. The roots collected were fixed in 70\% FAA (Johansen, 1940) for a period of $24 \mathrm{~h}$ and preserved in $70 \%$ ethanol. Free-hand cross-sections were made of primary roots 10 $\mathrm{cm}$ in length, using a microtome, and clarified in $20 \%$ sodium hypochlorite (Kraus and Arduin, 1997). Next, the sections were stained with $1 \%$ safranin and $1 \%$ aqueous alcian blue (Luque et al., 1996), dehydrated in an ethanol series, cleared in butyl acetate, and mounted in synthetic resin (Paiva et al., 2006). All sections were made from the tap root and from lateral ones. 


\section{RESULTS AND DISCUSSION}

The four specimens studied showed anatomical differences in the epidermis, exodermis, cortical parenchyma, and number of vascular poles. The differences are described in Table 1.

\begin{tabular}{|c|c|c|c|c|c|c|}
\hline & \multicolumn{2}{|c|}{ Epidermis } & \multirow[t]{2}{*}{ Exodermis } & \multirow[t]{2}{*}{$\begin{array}{l}\text { Cortical parenchyma } \\
\text { (at } 7 \mathrm{~mm} \text { to root tip) }\end{array}$} & \multicolumn{2}{|c|}{$\begin{array}{c}\text { Number of } \\
\text { vascular poles }\end{array}$} \\
\hline & Tap root & Lateral root & & & Tap root & Lateral root \\
\hline M. fortalezensis & $\begin{array}{l}\text { Circular outer } \\
\text { cells with wall } \\
\text { thickened }\end{array}$ & $\begin{array}{l}\text { Circular to narrow } \\
\text { cells with walls } \\
\text { slightly thickened }\end{array}$ & $\begin{array}{l}\text { Circular to polygonal } \\
\text { (4-7 sides). Cells } \\
\text { longer than in varieties } \\
\text { UnB } 201 \text { and UnB } 122 \text {. }\end{array}$ & $\begin{array}{l}\text { Up to } 11 \text { layers. } \\
\text { Abundant druses }\end{array}$ & 5,6 & $4-6$ \\
\hline M. glaziovii & & $\begin{array}{l}\text { Circular to tabular } \\
\text { cell with wall } \\
\text { slightly thickened }\end{array}$ & & $\begin{array}{l}\text { Up to } 10 \text { layers. } \\
\text { Rare druses }\end{array}$ & 4,5 & 4 \\
\hline $\begin{array}{l}\text { M. esculenta } \\
\text { Crantz (variety } \\
\text { UnB 201) }\end{array}$ & & $\begin{array}{l}\text { Circular } \\
\text { cells with } \\
\text { thickened wall }\end{array}$ & $\begin{array}{l}\text { Circular to polygonal } \\
\text { (4-7 sides). Cells } \\
\text { rounder than in } \\
\text { M. glaziovii and } \\
\text { M. fortalezensis }\end{array}$ & $\begin{array}{l}\text { Up to } 14 \text { layers. } \\
\text { Rare druses }\end{array}$ & 6,7 & 5 \\
\hline $\begin{array}{l}\text { M. esculenta } \\
\text { (variety UnB 122) }\end{array}$ & & $\begin{array}{l}\text { Circular to irregular } \\
\text { cells with thickened }\end{array}$ & & $\begin{array}{l}\text { Up to } 11 \text { layers. } \\
\text { Frequent druses }\end{array}$ & $5,6,8$ & 4,5 \\
\hline
\end{tabular}

The tap root in primary growth showed a cuticle and unistratified epidermis, which was formed by common epidermal cells with outer circular shape and thick wall (Figure 1A). These cells showed little variation in size. In M. esculenta variety UnB 122, the cells have an acute end and irregular shape (Figure 1B). Trichomes were short and broad, with rounded tips, and they were observed in both varieties (Figure 1C).

In all species studied, the exodermis is a uniseriate layer, which differs in shape. Its cells vary from circular to polygonal (4-7 sides) in shape, may be homogeneous and have outer periclinal walls, thick and lignified (Figure 1D), with 2-3 times the length of epidermal cells. Cultivated species have smaller-sized cells, with twice the length of epidermal cells.

The cortex was found to be composed of isodiametric cells of varying size and thin wall. Cells in the middle of the cortex are twice the size of other cortical cells. The parenchyma differed between species as to the content and number of layers, as described in Table 1. Calcium oxalate druses were also noted in the cortex (Figure 1E).

Endoderm was found to be formed by small, circular to square cells of uniform size, and the Casparian bands were present in the anticlinal walls (Figure 1F). In the variety UnB 122, it was also possible to observe Casparian bands in the periclinal walls (Figure 2A). The central cylinder was composed of uniseriate pericycle with circular to square, small cells involving other tissues. The primary phloem in all species studied consisted of 1-4 layers of polygonal to round cells with walls slightly thicker than the walls of the parenchyma (Figure 1E).

Primary xylem vessel elements with lignified walls and vessel gaps were observed. The number of vascular poles differed between species. In M. glaziovii, 4 and 5 poles were observed (Figure 2B), while 5 and 6 poles in M. fortalezensis (Figure 1F). In the variety UnB 201, 6 (Figure 2C) and sometimes 7 (Figure 2D) poles were observed. The variety UnB 122 showed 4, 5, 6 (Figure 2E) and sometimes 8 (Figure 2F) poles. Lateral roots were seen in front of vascular poles (Figure 3A). Surrounding xylem vessels were parenchyma cells of variable size and shape. The larger cells were present at the center to form pith, and cells varied in shape from circular to polygonal. 

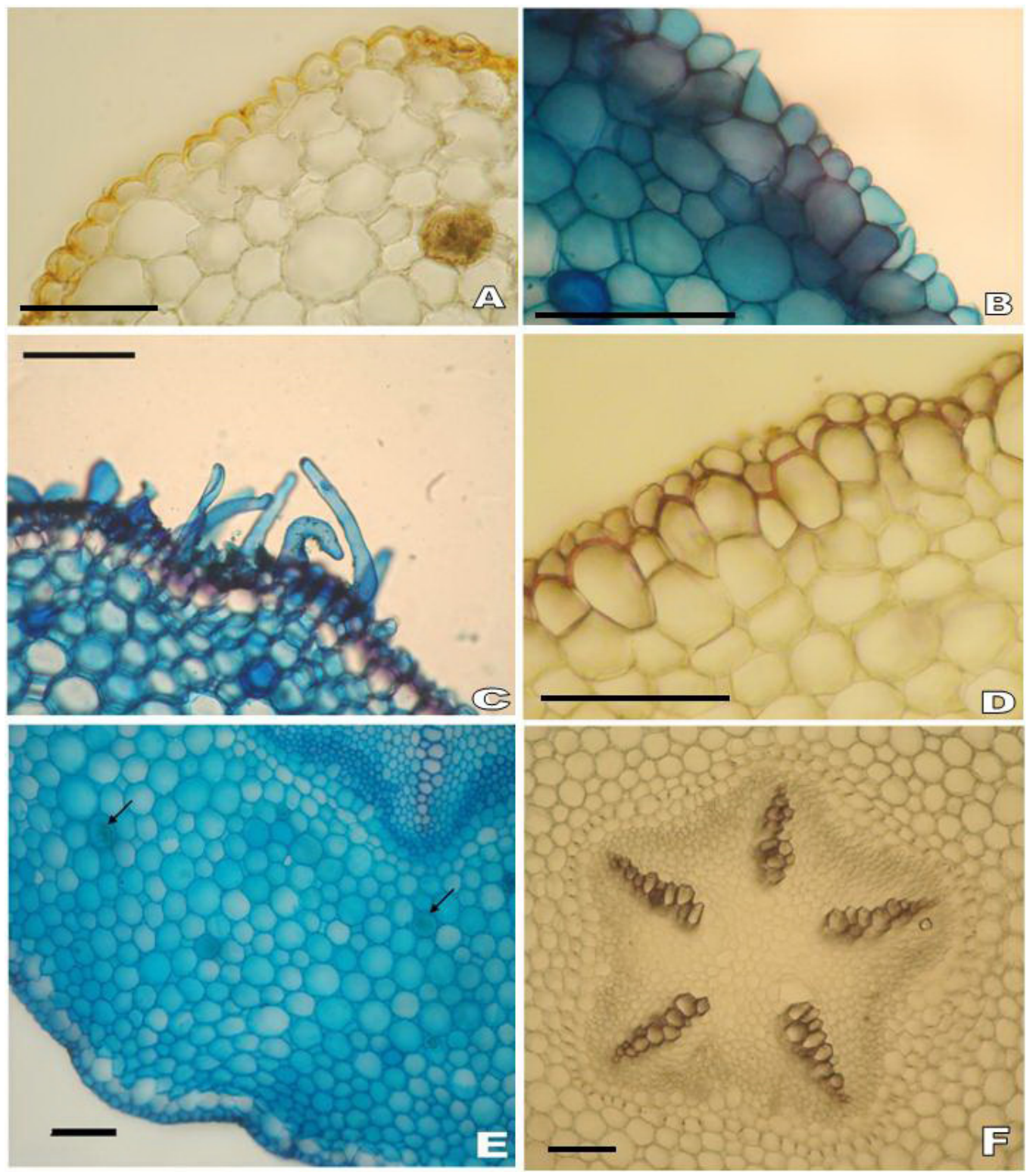

Figure 1. A. Epidermal cells with thick walls in Manihot esculenta variety UnB 201. B. Epidermal cells with acute end and irregular shape in M. esculenta variety UnB 122. C. Trichomes short and broad, with rounded tip in M. esculenta variety UnB 122. D. Exodermal cells with thick and lignified outer periclinal wall in $M$. fortalezensis. E. Cortical parenchyma with calcium oxalate druses (arrows) in $M$. fortalezensis. F. Casparian bands on anticlinal walls of exodermal cells in M. fortalezensis with $7 \mathrm{~mm}$ to root tip (tap root). Bar: $100 \mu \mathrm{m}$. 

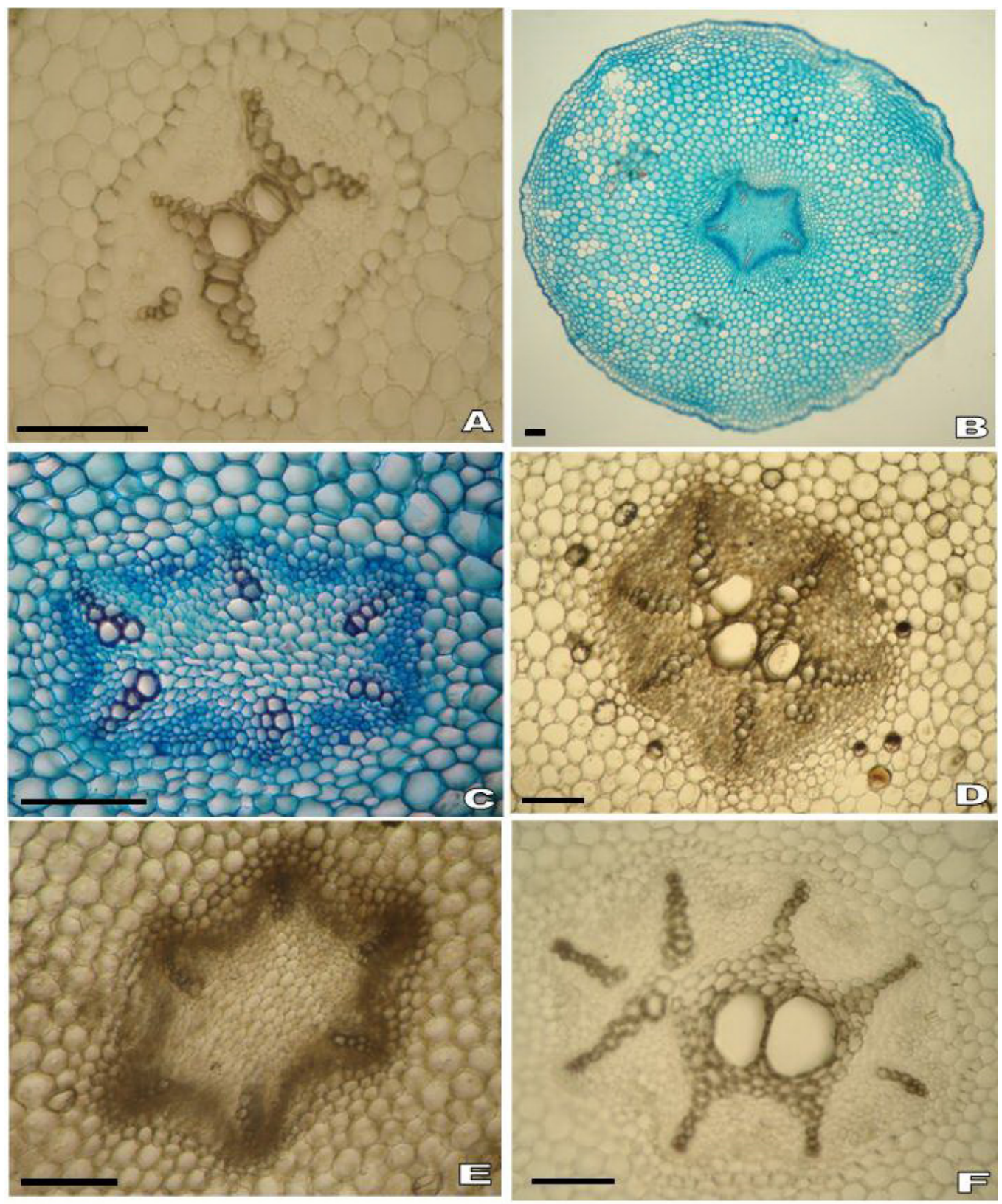

Figure 2. A. Casparian bands on anticlinal and periclinal walls of endodermal cells in Manihot esculenta variety UnB 122 (lateral root). B. Cross-section of M. glaziovii with 5 vascular poles (tap root). C. Six vascular poles in M. esculenta variety UnB 201 (lateral root). D. Seven vascular poles and cortical parenchyma $M$. esculenta variety UnB 201 (tap root). E. Six vascular poles in M. esculenta variety UnB 122, $7 \mathrm{~mm}$ to root tip (tap root). F. Eight vascular poles and Casparian bands on anticlinal walls of endodermis in M. esculenta variety UnB 122 (tap root). Bar: $100 \mu \mathrm{m}$. 

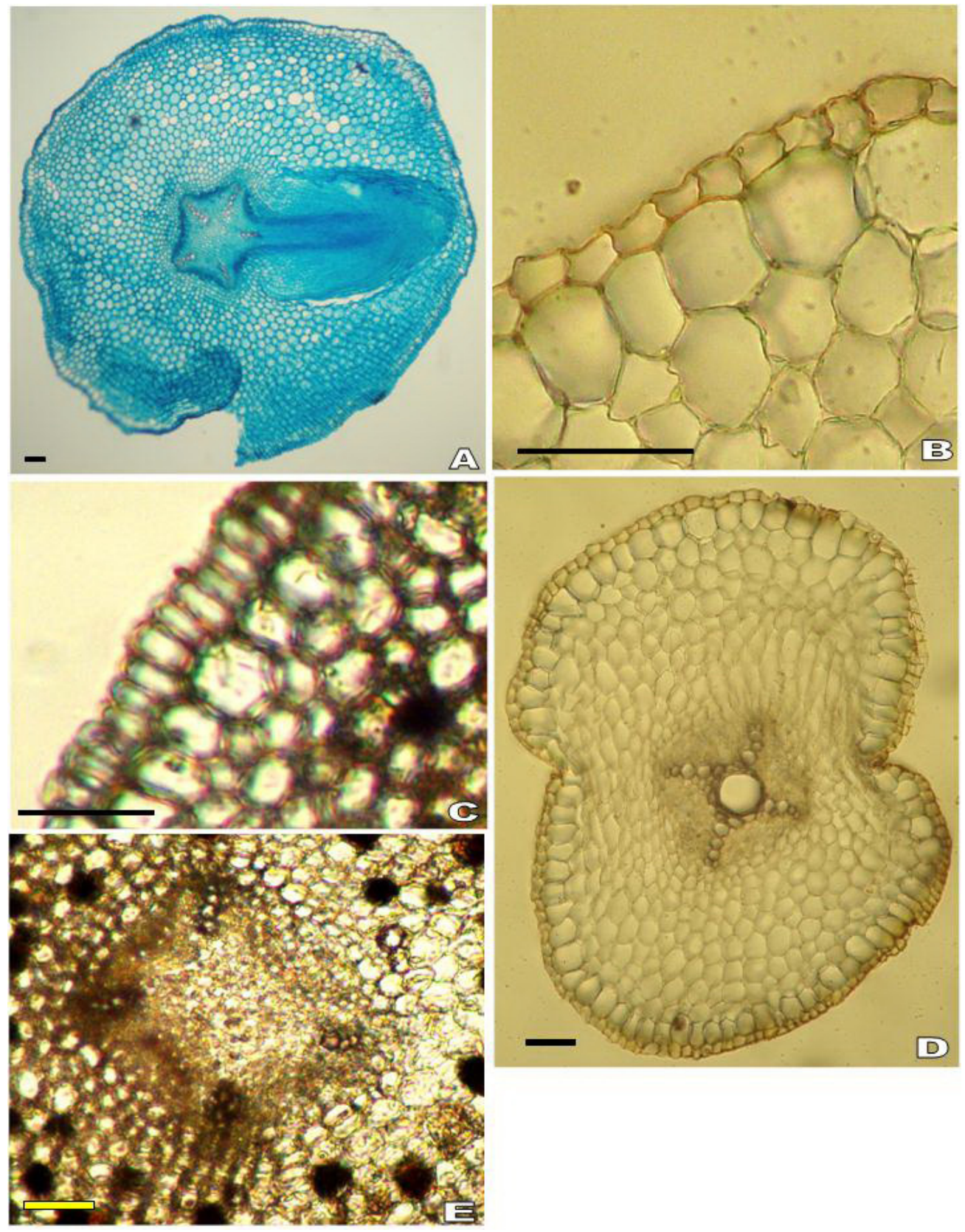

Figure 3. A. Lateral root emission in Manihot glaziovii. B. Tabular epidermal cells with thick wall in $M$. glaziovii (lateral root). C. Narrow epidermal cells with thick wall in M. fortalezensis (lateral root). D. Four vascular poles in lateral root of $M$. glaziovii in $7 \mathrm{~mm}$ to root tip. E. Four vascular poles in lateral root of $M$. glaziovii, $7 \mathrm{~mm}$ to root tip. Bar: $100 \mu \mathrm{m}$. 
The lateral roots showed a structure similar to that of the tap root, except for the shape of common epidermal cells in M. glaziovii and M. fortalezensis. Circular to tabular epidermal cells were observed in M. glaziovii (Figure 3B), while in M. fortalezensis, cell shape was circular to narrow (Figure 3C). The number of poles of the vascular system also varied between the lateral roots and tap roots. M. glaziovii had lateral roots with 4 poles and the center occupied by the vascular vessel (Figure 3D). M. fortalezensis exhibited 4 poles (Figure 3E), sometimes 5 and 6 poles in the lateral roots. The variety UnB 201 showed 5 poles, while in the variety UnB 122 there were 4 and 5 poles.

The thickness of epidermal and exodermal cell walls may have significance in relation to drought and tolerance to disease, because Casparian bands and suberin lamellae may restrict water loss (Peterson et al., 1993) and pathogen colonization (Schreiber et al., 1994). There are reports on the increase of cell wall thickness in plants under drought conditions (Cruz et al., 1992; Mostajeran and Rahimi-Eichi, 2008). All Manihot species studied here have thick cell walls of epidermis and the outer periclinal walls of the exodermis being thick. This finding may help understand the rustic characteristic in the Manihot species reported by Nassar et al. (2008, 2010), Graciano-Ribeiro (2008), and Graciano-Ribeiro et al. (2009).

Within the Euphorbiaceae, some genera such as Euphorbia have their roots with 3 or 4 poles (Gales and Toma, 2006), while Jatropha cordata, a species belonging to the same subfamily of Manihot, has 2 vascular poles (Popham, 1947). Manihot pilosa and M. esculenta have 4 or 5 poles (Indira and Kurian, 1977; Vanucci, 1982), and 6 poles (Moraes-Dalaqua and Coral, 2002), but this is the first report of more than 6 poles in Manihot species and the plants studied. Variation in the same species is frequently reported (Esau, 1965). Although Manihot species are dicots, they showed more than 4 poles and lateral root position in front of poles. These characteristics are commonly reported in monocotyledons (Rudall, 2007).

While $M$. glaziovii showed a very limited variation in pole number, cassava (varieties UnB 201 and UnB 122) exhibited variation ranging from 5 to 8 poles. The variation in pole number of cassava cultivars studied here may support the hypothesis of hybrid origin of the cultigen where segregation is likely to produce this notable variation (Nassar, 2002, 2003a,b).

\section{ACKNOWLEDGMENTS}

Thanks are due to the Conselho Nacional de Desenvolvimento Científico (CNPq) for support, and to CAPES-Brasília for a scholarship to N.N. Bomfim. The above living collection was established at the Universidade de Brasília with the help of the Canadian International Development Research Center (IDRC) to which we are grateful.

\section{REFERENCES}

Chacón J, Madriñan S, Debouck D, Rodriguez F, et al. (2008). Phylogenetic patterns in the genus Manihot (Euphorbiaceae) inferred from analyses of nuclear and chloroplast DNA regions. Mol. Phylogenet. Evol. 49: 260-267.

Cruz RT, Jordan WR and Drew MC (1992). Structural changes and associated reduction of hydraulic conductance in roots of Sorghum bicolor L. following exposure to water deficit. Plant Physiol. 99: 203-212.

Esau K (1965). Plant Anatomy. 2nd edn. Wiley \& Sons, New York.

Gales RC and Toma C (2006). Comparative anatomy of the vegetative organs of some Euphorbia species (Euphorbiaceae Juss.) from the Romanian flora. Rom. J. Biol. - Plant Biol. 51: 39-47.

Graciano-Ribeiro D (2008). Anatomy of polyploid Cassava and its interspecific hybrids. Gene Conserv. 7: 620-635.

Graciano-Ribeiro D, Hashimoto DYC, Nogueira LC and Nassar NMA (2009). Vascular bundles in Manihot esculenta 
Crantz (Euphorbiaceae). Gene Conserv. 8: 808-817.

Indira P and Kurian T (1977). A study on the comparative anatomical changes undergoing tuberization in the roots of cassava and sweet potato. J. Root Crops 3: 29-32.

Johansen DA (1940). Plant Microtechnique. McGraw Hill, New York.

Kraus JE and Arduin M (1997). Manual Básico de Métodos em Morfologia Vegetal. Seropedica, Rio de Janeiro.

Luque R, Sousa HC and Kraus JE (1996). Métodos de coloração de Roeser (1972) - modificado - e Kropp (1972) visando a substituição do azul de astra por azul de alcião 8GS ou 8GX. Acta Bot. Bras. 10: 199-212.

Moraes-Dalaqua MA and Coral DJ (2002). Morfo-anatomia. In: Cereda MP (Coord.). Agricultura: Tuberosas Amiláceas Latino-Americanas. Fundação Cargill, São Paulo, 540.

Mostajeran A and Rahimi-Eichi V (2008). Drought stress effects on root anatomical characteristics of rice cultivars (Oryza sativa L.). Pak. J. Biol. Sci. 11: 2173-2183.

Nassar NMA (1986). Genetic variation of wild Manihot species native to Brazil and its potential for cassava improvement. Field Crops Res. 13: 177-184.

Nassar NMA (2001). Cassava, Manihot esculenta Crantz and wild relatives: Their relationships and evolution. Genet. Res. Crop Evol. 48: 429-436.

Nassar NM (2002). Cassava, Manihot esculenta Crantz, genetic resources: origin of the crop, its evolution and relationships with wild relatives. Genet. Mol. Res. 1: 298-305.

Nassar NM (2003a). Cassava, Manihot esculenta Crantz genetic resources: VI. Anatomy of a diversity center. Genet. Mol. Res. 2: 214-222.

Nassar NM (2003b). Gene flow between cassava, Manihot esculenta Crantz, and wild relatives. Genet. Mol. Res. 2: 334-347.

Nassar NM, Hashimoto DY and Fernandes SD (2008). Wild Manihot species: botanical aspects, geographic distribution and economic value. Genet. Mol. Res. 7: 16-28.

Nassar NM, Abreu LF, Teodoro DA and Graciano-Ribeiro D (2010). Drought tolerant stem anatomy characteristics in Manihot esculenta (Euphorbiaceae) and a wild relative. Genet. Mol. Res. 9: 1023-1031.

Nichols RFW (1947). Breeding cassava for resistance. East Afr. Agr. J. 12: 184-194.

Paiva JGA, Fank-de-Carvalho SM, Magalhães MP and Graciano-Ribeiro D (2006). Verniz vitral incolor 500 ${ }^{\circledR}$ : a mounting medium alternative and economically viable. Acta Bot. Bras. 20: 257-264.

Peterson CA, Murrmann M and Steudle E (1993). Location of the major barriers to water and ion movement in young roots of Zea mays L. Planta 190: 127-136.

Popham RA (1947). Developmental anatomy of seedling of Jatropha cordata. Ohio J. Sci. 47: 1-20.

Rudall PJ (2007). Anatomy of Flowering Plants. An Introduction to Structure and Development. Cambridge University Press, New York.

Schreiber L, Breiner HW, Riederer M, Duggelin M, et al. (1994). The Casparian strip of Clivia miniata Reg. roots: isolation, fine structure and chemical nature. Bot. Acta 107: 353-361.

Vanucci A (1982). Anatomia Comparada de Duas Espécies Manihot Miller (Euphorbiaceae). Master's tesis, Unicamp, Campinas. Available at [http://cutter.unicamp.br/document/?code=vtls000048501]. Accessed October 3, 2010. 